\title{
POŚTA
}

TELEKOMUNIKÁCIE A

ELEKTRONICKY OBCHOD

Qlets

ccl?

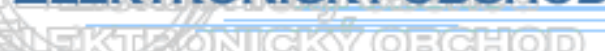

\section{FAKTORY OVPLYVŇUJÚCE ÚSPEŠNOSŤ PROJEKTOVÉHO RIADENIA A RIADENIE RIZÍK PROJEKTU}

\author{
Soňa Stránska*, Iveta Kremeňová*
}

\section{Úvod}

Projektové riadenie je pomerne náročná manažérska disciplína, ktorá zabezpečuje efektívne využitie l'udských zdrojov, zariadení, finančných prostriedkov a času spojeného s realizáciou

projektu.

Článok charakterizuje špecifiká projektového riadenia, zaoberá sa charakteristikou faktorov úspešnosti projektov, zhodnotením rizík projektového riadenia. Projektové riadenie predstavuje manažérsku disciplínu pre organizovanie a koordinovanie zdrojov takým spôsobom, aby projekt bol dokončený v stanovenom rozsahu, kvalite, termíne a nákladoch.

Riadenie rizík zahŕňa identifikáciu rizík, analýzu rizík, plánovanie odoziev na riziká, vyhodnocovanie rizík a realizáciu protiopatrení. Analýza rizika a riadenie rizika sú kontinuálne procesy a preto musia byt' vykonávané počas celého životného cyklu projektu.

Riadenie rizík projektu je jedným z klúčových aspektov pre dosiahnutie očakávaných ciel'ov projektu. Ochota prijat' a riadit' riziká projektu je často rozlišovacím prvkom medzi úspešným a neúspešným projektovým manažérom.

\section{Faktory úspešnosti projektov}

Pojem projektové riadenie možno špecifikovat' pomocou definície, ktorú uvádza Project Management Institut [1]: je to aplikácia znalostí, schopností, nástrojov a techník na projektové aktivity, ktoré vedú k splneniu požiadaviek projektu. Základným ciel’om projektového riadenia je dodat' výsledok včas, s úplnou funkciou a kvalitou a s dodržaním nákladov (jedná sa o tzv. faktory OTIFOB - on time, in full, on budget). Projekt je charakterizovaný ako dočasné úsilie vynaložené na vytvorenie jedinečného produktu alebo služby prostredníctvom celej rady koordinovaných a riadených činností. Kl'účovým $\mathrm{v}$ definícii projektu je význam slov:

- dočasný znamená, že má jednoznačný začiatok a koniec,

- jedinečný znamená, že produkt alebo služba sa niečím odlišuje od všetkých ostatných produktov a služieb.

V rámci projektového riadenia správne stanovenie ciel'ov a premyslené naplánovanie ich realizácie zásadne zvyšuje výkonnost' spoločností pri riešení projektov. Mnohé štatistiky

\footnotetext{
* Ing. Soňa Stránska, Žilinská univerzita v Žiline, Fakulta prevádzky a ekonomiky dopravy a spojov, katedra spojov, Univerzitná 1, 01026 Žilina,

e-mail: sona.stranska@fpedas.uniza.sk

* doc. Ing. Iveta Kremeňová,PhD., Žilinská univerzita v Žiline, Fakulta prevádzky a ekonomiky dopravy a spojov, katedra spojov, Univerzitná 1, 01026 Žilina,

e-mail: iveta.kremenova@fpedas.uniza.sk
} 
z oblasti projektového riadenia dokazujú, že pokial' sa nevenuje dostatok pozornosti fáze plánovania, nastanú komplikácie a nepríjemnosti v nasledujúcich etapách projektu až do podoby „hasenia požiaru“. Pre úspešné vedenie projektu je preto nevyhnutné dôsledné, primerane detailné a zároveň realistické plánovanie. Plánovanie aktivít projektu, ich trvanie a väzby umožňujú mnohé podporné softwarové nástroje pre zobrazenie Ganttovho grafu, resp. diagramu PERT.

Teda ciel'om plánovania projektu je zaistit':

- najkratší možný čas trvania projektu (súvisí tiež s nákladmi),

- najnižšie náklady,

- najmenšie riziko,

- efektívne využitie zdrojov pri zachovaní štandardu kvality.

Plánovat' znamená vopred určovat', aké udalosti alebo akcie by mali nastat', kedy a v akom poradí by mali nastat', kde by mali nastat', ako ich treba realizovat', kto by ich mal realizovat' a s akými zdrojmi. Základom plánovania je presný odhad budúcich udalostí a to vždy sčasti vychádza najmä zo skúseností projektového manažéra. Obecne je možné zhrnút' najčastejšie rizikové faktory projektového plánovania a riadenia takto:

$>$ Vel'ký tlak na výkon: „rýchlejšie, lepšie, lacnejšie“.

$>$ Zle definované ciele.

$>$ „Zmutovanie“ výsledku projektu do nečakanej podoby.

> Zlé odhady - príliš optimistické plány, zanedbané detailné plánovanie pod časovým tlakom.

$>$ Prehnané očakávania prínosov projektu.

$>$ Nedostatok kvalitných zdrojov.

$>$ Nedostatok podpory manažmentu.

> Nerealistický harmonogram - nevhodné návrhy riešení pre dané reálne podmienky.

$>$ Neskúsený projektový manažér.

$>$ Zlá metodológia - stratové činnosti (,plytvanie“).

$>$ Neadekvátna kontrola, monitorovanie - nedôsledné kontrolné mechanizmy.

Problematické oblasti projektového riadenia sú podrobne popísané v tabul'ke 1:

- riadenie požiadaviek,

- riadenie rizík,

- riadenie míl'nikov a postupu prác,

- riadenie aktivít na kritickej ceste,

- riadenie projektových zdrojov,

- riadenie kvality

\begin{tabular}{|l|l|}
\hline $\begin{array}{l}\text { Faktor } \\
\text { Zlyhanie }\end{array}$ & \multicolumn{1}{c|}{ Dôsledok } \\
\hline \multicolumn{2}{|c|}{ Riadenie požiadaviek } \\
- definovanie charakteristík, funkcií, dát a systémov použitých v rámci projektu, zhoda \\
s klientom o rozsahu projektu
\end{tabular}




\begin{tabular}{|c|c|}
\hline $\begin{array}{l}\text { Chýba riadenie rizík a nie je pripravený } \\
\text { krízový scenár, indikátory nie sú sledované, } \\
\text { riziká sú identifikované, ale nie sú vytvorené } \\
\text { plány na ich elimináciu, nedostatok } \\
\text { následného riadenia rizík }\end{array}$ & $\begin{array}{l}\text { Postup spomalený/zastavený uskutočnením } \\
\text { hrozieb, krízový manažment }\end{array}$ \\
\hline \multicolumn{2}{|c|}{$\begin{array}{l}\text { Riadenie míl’nikov a postupu prác } \\
\text { j báze, či postup zodpovedá plánu a sú splnené }\end{array}$} \\
\hline $\begin{array}{l}\text { Pôvodný plán nie je dostatočne flexibilný pri } \\
\text { zistení odchýlok, neschopnost' stanovit', či je } \\
\text { projekt na správnej ceste, nespozorovaný } \\
\text { vplyv malých oneskorení }\end{array}$ & $\begin{array}{l}\text { Náhle odhalenie, že projekt nebude dodaný } \\
\text { včas, predíženie o týždne/mesiace, eliminácia } \\
\text { kontrolných mechanizmov }\end{array}$ \\
\hline \multicolumn{2}{|c|}{$\begin{array}{l}\text { Riadenie aktivít na kritickej ceste } \\
\text { - identifikácia závislých úloh, ktoré majú zásadný vplyv na dížku projektu a jeho dokončenie, } \\
\text { monitorovanie aktivít pozdĺž kritickej cesty }\end{array}$} \\
\hline $\begin{array}{l}\text { Zanedbanie analýzy kritickej cesty, } \\
\text { nedostatočné sledovanie aktivít na kritickej } \\
\text { ceste, žiadna aktualizácia analýzy a spätná } \\
\text { väzba; }\end{array}$ & $\begin{array}{l}\text { Pozornost' vedenia je zameraná nesprávne, } \\
\text { vplyv na skĺzavanie termínov sa nespozoruje } \\
\text { včas, oneskorenie aktivít na kritickej ceste sa } \\
\text { zistí neskoro }\end{array}$ \\
\hline \multicolumn{2}{|c|}{$\begin{array}{l}\text { Riadenie projektových zdrojov } \\
\text { - vytvorenie pravdivého odhadu l'udských zdrojov a ostatných zdrojov, identifikovanie } \\
\text { výstupov, aktivít a ich súslednost', komunikácia }\end{array}$} \\
\hline $\begin{array}{l}\text { Plány založené len na odhadoch, nie na } \\
\text { pravdivých podkladoch, príliš optimistické } \\
\text { odhady, nedostatok medzných míl'nikov, } \\
\text { kontrol výstupov, nedostatočné porovnanie } \\
\text { aktivít s plánom, žiadna aktualizácia plánu }\end{array}$ & $\begin{array}{l}\text { Nepresné stanovenie zdrojov, nad/pod } \\
\text { hodnotenie potreby zdrojov, neschopnost' } \\
\text { splnit' harmonogram; }\end{array}$ \\
\hline \multicolumn{2}{|c|}{$\begin{array}{l}\text { Riadenie kvality } \\
\text { - uistenie, že dodané funkcie produktu zodpovedajú špecifikáciám, dokumentácia zodpovedá } \\
\text { systému, systém je udržatel'ný, všetci „zákazníci sú spokojní“; }\end{array}$} \\
\hline $\begin{array}{l}\text { Žiadne zhodnotenie čiastkových } \\
\text { projektových výstupov, nedostatočný základ } \\
\text { pre hodnotenie, nedostatok projektových } \\
\text { štandardov, nedostatočné testovanie z } \\
\text { dôvodov časovej tiesne, nedostatočné } \\
\text { sledovanie kvality. }\end{array}$ & $\begin{array}{l}\text { Kvalita je premenlivá a je nepredvídatel’ná } \\
\text { do ukončenia projektu. }\end{array}$ \\
\hline
\end{tabular}

Tabul'ka 1 : Kritické faktory riadenia rizík

\section{Riadenie rizík projektu}

Riadenie rizík projektu je proces analýzy rizík (definovanie, kategorizácia a kvantifikácia rizík v zozname rizík), plánovania opatrení pre všetky riziká projektu (vrátane indikátorov možného výskytu príslušného rizika), uplatnenia týchto opatrení a kontroly účinnosti týchto opatrení.

Riziká sa môžu týkat' vonkajšieho prostredia projektu (politické, sociálne, finančné, technické, ekologické), alebo vnútorného prostredia projektu (technológia prác, rozpočtové riziká, riziká týkajúce sa prostriedkov a l’udí nasadených na projekte).

Riadenie rizík zahŕňa: 
Identifikáciu rizík - vymedzuje, ktoré riziká môžu mat' vplyv na projekt

> Kvalitatívna a Kvantitatívna Analýza Rizík - určovanie priority rizík a výpočtová analýza dopadov rizík na všetky projektové výstupy

> Odozva na Riziká - príprava alternatív a opatrení na rozširovanie príležitostí a znižovanie hrozieb pre projektové výstupy[2]

\subsection{Charakteristické znaky rizika}

- Riziko je udalost', ktorá sa môže stat' v budúcnosti.

Niekedy považujeme udalosti, ktoré sa stali v minulosti za príčinu prebiehajúcich problémov, kríz. Ak sa tieto udalosti stali v minulosti, nie sú príkladom rizika. Riziko musí byt' udalost'ou v budúcnosti. Preto termíny ako sú náklady, plán, vykonaná práca nespadajú do definície rizika, pretože nie sú udalosti. Riziká sú udalosti, ktoré súvisia s uvedenými termínmi a uskutočnia sa v budúcnosti (napr. určovanie, meranie vykonanej práce môže byt' rizikom). S udalost’ou spájaný účastník projektu, alebo určité miesto kde je projekt vykonávaný spadajú pod definíciu rizika pričom samotné termíny miesto a účastník projektu nie (pretože nie sú udalost').

- pravdepodobnost', že sa udalost' v budúcnosti stane musí byt' väčšia ako 0 a menšia ako $100 \%$. Vel'ké množstvo udalostí spadá do tohto rozsahu avšak iba niektoré z nich sú riziká. V prípade udalosti, ktorá sa stane na $100 \%$ nehovoríme o riziku, ale o kríze alebo zásadnom probléme.

- následky predmetných budúcich udalostí musia byt' neočakávatel'né, nenaplánované.

Dôsledky môžu byt' pozitívne, alebo negatívne. Riadenie rizík v rámci projektu rozlišuje formalizovaný prístup k procesu ako protiklad k intuitívnemu prístupu. Riadenie rizík sa teda zaoberá vytvorením plánu protiopatrení pre konkrétne, stanovené riziká, sledovaním spúšt’ačov identifikovaných aj nových rizík, vykonávaním proti rizikových opatrení a kontrolou dopadov jednotlivých rizík. Riadenie rizík je umenie a veda ako plánovat', identifikovat' a analyzovat' riziká (posudzovanie rizík), zvládanie rizík a sledovanie akcií vedúcich k prijatel'nému zvládnutiu rizík. Riadenie rizík je proaktívne. Naproti tomu krízové riadenie je reaktívne. Proces riadenia rizík sa vyskytuje vo všetkých fázach životného cyklu projektu.

\subsection{Dôvody prečo riadit’ riziká}

Podmienky projektov sa neustále menia. Čím d'alej viac je snaha realizovat' projektov pri zmenšenom (napnutom) rozpočte a v čo najkratšom časovom horizonte, samozrejme $\mathrm{s}$ čo najnižšími nákladmi na materiálové a l’udské prostriedky.

Pridaná hodnota - hodnota riadenia rizika nespočíva iba v zabránení analyzovaného rizika. Schopnost' dodávatel'a riešit' riziká projektu je jedným z kl'účových prvkov (konkurenčnou výhodou) pri výbere dodávatel'a pri výberovom konaní.

Metódy zvládnutia rizika pomáhajú projektovému manažérovi pri denno - denných rozhodnutiach $\mathrm{v}$ rámci riadenia projektu

Oficiálne postupy - pomáhajú zistit’ podstatu problému (nie jeho sprievodné javy), čo prispieva k nájdeniu riešenia. 


\subsection{Proces riadenia rizík projektu}

Analýza rizika a riadenie rizika sú kontinuálne procesy a preto musia byt' vykonávané počas celého životného cyklu projektu. Osobitne je potrebné zdôraznit' analýzu rizík ešte pred začiatkom projektu. Štúdia uskutočnitel'nosti je vykonávaná za účelom zistenia obsahu, rozsahu, predmetu projektu s väzbou na samotné prostredie pripravovaného projektu. Práve v tejto etape je potrebné analyzovat' uskutočnitel'nost' projektu prostredníctvom získaných informácií o rizikách a príležitostiach.

Každé zistené riziko je vhodné situovat' do tzv. matice rizík. Určujúcim prvkom pre umiestnenie rizika do matice rizík je odhadovaná pravdepodobnost' výskytu a pravdepodobný finančný dopad rizika na projekt. Pohl'ad na konkrétne predpokladané riziko v matici rizík nám poskytne obraz o prijatel'nosti či neprijatel'nosti uvedeného rizika a umožní porovnanie jednotlivých rizík.

Ochota prijat' a riadit' riziká projektu je často rozlišovacím prvkom medzi úspešným a neúspešným projektovým manažérom. V priebehu projektu je samotný projektový manažér vystavený riziku nesprávnej vol'by - rozhodnutia, ak účastník projektu (napr. užívatel') popisuje problém chybne (navyše zdanlivo logicky správne).

Z praktických skúseností môžeme definovat' nasledujúce prvky :

- nutnost' rozdelit' projektové ciele a úlohy ako výstupy konkrétnych procesov

- výstupom brainstormingu je v praxi najčastejšie používaný kontrolný zoznam rizík

- príčiny rizík a samotné rizikové udalosti sú často zamenitel’né

- väčšia váha sa prisudzuje dôsledkom rizika než pravdepodobnosti výskytu rizika

- čiastočne analýzy rizika môžu byt' použité iba za primeraných okolností

- pre každý proces riadenia rizika je potrebné zvolit' vhodný prístup

Všeobecne existuje pät' typov opatrení na zníženie rizika:

- zamedzenie/odstránenie možnosti výskytu rizika,

- zmenšenie dopadov rizika,

- poistenie (plánovanie finančných rezerv),

- prenos rizika alebo

- prijatie rizika

Tieto opatrenia bud' zmenšujú, alebo obmedzujú dopad rizík na projekt. Dokumentovanie rizík a kontrola opatrení pri výskyte rizík sú doplňujúcimi úlohami riadenia rizík. Pre projektové riadenie má význam nielen riadenie rizika, ale aj riadenie príležitostí.

Poistná rezerva projektu je množstvo peňazí, prostriedkov alebo času, potrebné na zníženie následkov rizík projektu na úroveň, únosnú pre účastníkov projektu. Plánovanie poistných rezerv je vypracovanie súboru stratégií na zabezpečenie úspechu projektu ak nastanú predpokladané rizikové udalosti (riziká). [3]

\section{Záver}

Súčasné trhové prostredie sa vyznačuje ostrou konkurenciou, kratšími životnými cyklami výrobkov a kratším časom medzi inováciami.Západné spoločnosti dnes považujú znalost' projektového riadenia za samozrejmost' a bežne ho používajú. Projekty sú často rozhodujúcou súčast'ou strategického riadenia podniku. Projektové riadenie je komplexný proces, ktorý si vyžaduje profesionálny prístup a podporu vrcholového manažmentu organizácie, ako aj efektívnu tímovú prácu. 


\section{Literatúra}

[1] Project Management Practice,The Professional Magazine of the International Project Management Association, ISSUE 5 - SPING 2006

[2] KOVÁČ,M., LEŠKOVÁ, A..: Projektové riadenie, edícia EQUAL, 2006, ISBN 80-8073491-7

[3] KENDRICK, T.: Identifying and Managing Project Risk, American Management Association, 2003, ISBN 0-8144-0761-7 